\title{
Effect of the Spudcan's Footprints on Nearby Jacket's Mudmat in Clayey Soil-Case Study
}

\author{
Omrani Zahra $^{1}$, Amirabadi Rouhollah ${ }^{2}$ \\ ${ }^{I}$ PHD Candidate of Civil Engineering, University of Qom, Iran; z.omrani@stu.qom.ac.ir \\ ${ }^{2}$ Asistant Professor of University of Qom, Iran; R.amirabadi@qom.ac.ir
}

\section{ARTICLE INFO}

Article History:

Received: 11 Sep. 2016

Accepted: 7 Jan. 2017

\section{Keywords:}

Spudcan

Mudmat

Clayey

Jack-up

Instability

\begin{abstract}
When a jack-up installed at a clay location and then leaves; it can create several meter deep footprints. In case of soft clay, the spudcan may have actually penetrated much deeper than the observed footprints. When the penetrated spudcan is pulled out, much of the soft remolded clay will flow around it and go back into the hole. This event, leaving a deep region of disturbed soil. The disturbed soil has a lower strength and stiffness in comparing to intact material around. The footprints and the associated remolded soil can potentially present significant hazards for subsequent jackup or jacket deployments at the same location for example the events in China Sea and Pesian Gulf of Iran.

In this research a case study and numerical simulation (using commercial software ABAQUS) was performed to analyze the effects of spudcan penetration on the adjacent foundations of offshore platforms in clayey soil. Inconsistent with other studies, it was also shown that the penetration of spudcan can affect the soil layer in an annular zone. The maximum width of the affected zone is almost two times of the spudcan diameter; therefore the safe distance for installation of new nearby structures is also affected. In this paper the consequence of deployment of jack-up units in soft to firm clay will be discussed and the safe distance from footprints territory is obtained. All of our cases are located in the Persian Gulf. A jacket location of Assaluyeh/South Pars Gas Field in Persian Gulf was modeled to verify the numerical results. The most important results were the diameter of disturbed soil is 1.5-2 times the spudcan diameter and the safe distance from the territory of footprint is 3$4 \mathrm{~m}$ in the Persain Gulf zone.

These findings will help offshore geotechnical engineers to perform quick preliminary estimates on the severity of footprint-mudmat interaction problems.
\end{abstract}

\section{Introduction}

Jack-up rigs are mobile drilling units that used in offshore for hydrocarbon exploration and production activities. During exploratory activities no structure exists near jack-up position. However, during production Phase, they are initially deployed for drilling next to wellhead platforms and a long time later for work-over operation purposes. In areas where jack-up rigs are deployed, the soil disturbance is a matter of considerable interest for proper design of near foundations as well as for the redeployment of jack-up units at the same site in the future. While deploying a jack-up rig, the large foundations at their bottom so called spudcans are pushed into the seabed for safety and stability during its operation. In soils of soft to firm consistency, the legs penetrate up to a significant depth below the seabed. Such penetration followed by the withdrawal of the spudcans after operation cause large movement of soil in all directions and at the same time reduce the strength of soil due to remolding in and around the penetration path [1].In order to control the sliding risk for a jackup platform re-installation or jacket mudmat close to an existing footprint, a safe distance from footprints should be considered. For finding a safe distance, some research was done by Dongfeng et al.; They concluded the optimal stamping offset distance for jack up re-installation is $1.25 \mathrm{D}$ ( $\mathrm{D}$ is the footprint diameter) [2]. Generally Jacket platforms that used in offshore for oil extractions are temporarily supported 
by mudmats during installation. These platforms are not always installed on virgin seabed, but are sometimes located close to features such as footprints formed by previous deployments of jack-up rigs. Therefore, the effects of the spudcan penetration on the foundation of the platform should be considered [3]. However, there is a lack of information for placing the jacket mudmat near the footprints. The soil-structure interactions have been analyzed intensively by many researchers $[4,5]$. However, it isn't an easy task to obtain the exact solution of this problem because of the complexity [6-8]. These seabed features potentially influence the bearing capacity of the mudmat and should be considered in the stability verification. In-situ measurements of such cases of soil disturbance in actual sites are rarely carried out due to the high cost of offshore operations. Normally, estimation of such disturbed zones and the reduction of strength are measured approximately with available knowledge on the subject. In this paper, four cases of jack-up rig deployment in the offshore of the Persian Gulf are discussed; their investigations were made before and after the deployment of the rigs. The investigation result re-establishes some of the existing knowledge and provides new information; adding further confidence to the offshore geotechnical engineers. Unfortunately, as part of an extensive oil field development in the Deep Continental Shelf, Offshore Persian Gulf, a wellhead platform was sliding and sunk during placement on seabed. Through the site survey, it was discovered that the target's position was located next to large footprints. These footprints were formed earlier by a jack-up rig that had been deployed at the same location and caused mudmat instability. In addition to the financial loss to the Company, such incidents can damage the environment. Therefore, the safe distance from footprints in offshore operations is necessary and critical.

\section{Measurement of Jack-up Spudcan Penetration and Strength Reduction in clayey Soil}

Usually bearing capacity analysis is performed for penetration assessment of jack-up spudcans. The geometry of the spudcans, applied preload (extra loading to place the foundation with a safety margin against combined loads during operation) and the soil condition at the site are prerequisites to do this analysis. The bearing capacity analysis is based on the international practice [9] that determined from local experience in the area. During installation for commonly deployed jack-up units, the average vertical stress below the spudcans are in the range of 200 to $400 \mathrm{kN} / \mathrm{m}^{2}$ or more [10]. The penetration of the legs continues downward as long as the bearing stress below the spudcan is more than the bearing capacity of the soil. In our all four cases, due to jack up operation, soil resistance was reduced. The Geometry of spudcans and footprints and the soil details of our target cases in the Persian Gulf are mentioned below. In all four cases numerical modeling was performed which is explained in the case named Phase 13SPD13C.

\subsection{Case 1 (Phase 13-SPD 13D)}

The site water depth was $60.2 \mathrm{~m}$. The soil conditions and parameters were determined before the deployment of a rig through detailed investigation by carrying out CPTU (cone penetration test with pore pressure measurement) and detailed laboratory tests on recovered soil samples. Table 1 represents relevant parameters required for assessment of spudcan penetration. The soil profile is comprised of clay up to a depth of $20 \mathrm{~m}$.

Table 1: Soil properties at site for first case

\begin{tabular}{llllc}
\hline $\begin{array}{l}\text { Depth of } \\
\text { layer below } \\
\text { mud line }(\mathbf{m})\end{array}$ & $\begin{array}{l}\text { Soil } \\
\text { type }\end{array}$ & $\begin{array}{l}\mathbf{S}_{\mathbf{u}} \\
\left(\mathbf{k N} / \mathbf{m}^{2}\right)\end{array}$ & $\begin{array}{l}\boldsymbol{\varphi}^{\prime} \\
(\text { degree })\end{array}$ & $\begin{array}{l}\text { Effective } \\
\text { Unit wt. } \\
\left(\mathbf{k N} / \mathbf{m}^{\mathbf{3}}\right)\end{array}$ \\
\hline $0-20$ & clay & 12 & ---- & 7 \\
\hline
\end{tabular}

Note: $\mathrm{Su}$-Undrained shear strength, $\varphi^{\prime}$-drained angle of internal friction

In this case the rig was a three-legged unit and the equivalent spudcan (foundation) diameter was $15 \mathrm{~m}$. The shape of spudcan was conical at bottom and inside of the spudcan was filled with water during penetration into soil. The average penetration of the legs in this case was about $20 \mathrm{~m}$. After the withdrawal of the rig from the site, soil investigation was carried out at the three footprints of spudcans to ascertain the soil condition again. The investigation consisted of insitu test-CPTU along with sampling and laboratory testing. Footprints in the seabed due to deployment of jack-up unit and depression depth in two pits are shown in Figure 1(a) and Figure 1(b) respectively.

The investigation showed that soil has flown back into the footprints leaving depressions of $2.98 \mathrm{~m}$ to $3.28 \mathrm{~m}$ (in the three footprints) below the general seabed.

Reduction of undrained strength was evaluated for the top $20 \mathrm{~m}$ soil again by CPTU method. The CPTU cone resistance seems to be a very good measure of the undrained shear strength of the clay soil [11]. As already mentioned, CPTU was carried out twice before and after the jack-up rig deployment. Therefore, cone resistance in both situations was considered for evaluation of the undrained shear strength.

The strength ratio of original to the disturbed condition at different depths was evaluated after adjusting for the depth of the depression in the footprint area. The average ratio of soil strength reduction was 10 and this value of the ratio is found to be close to the upper limit of recommended values of sensitivity. Sensitivity is used for analysis of foundation that has been installed in the area; however the term "sensitivity", in the true sense of the term 


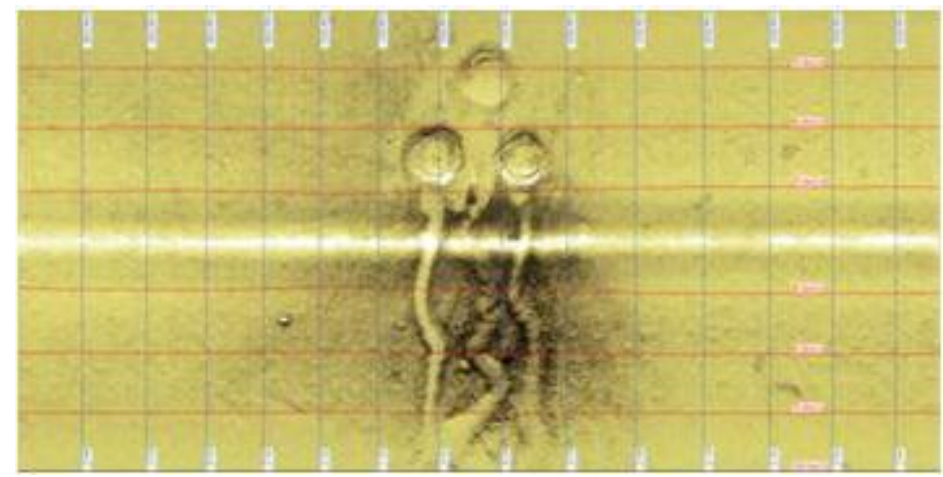

(a)
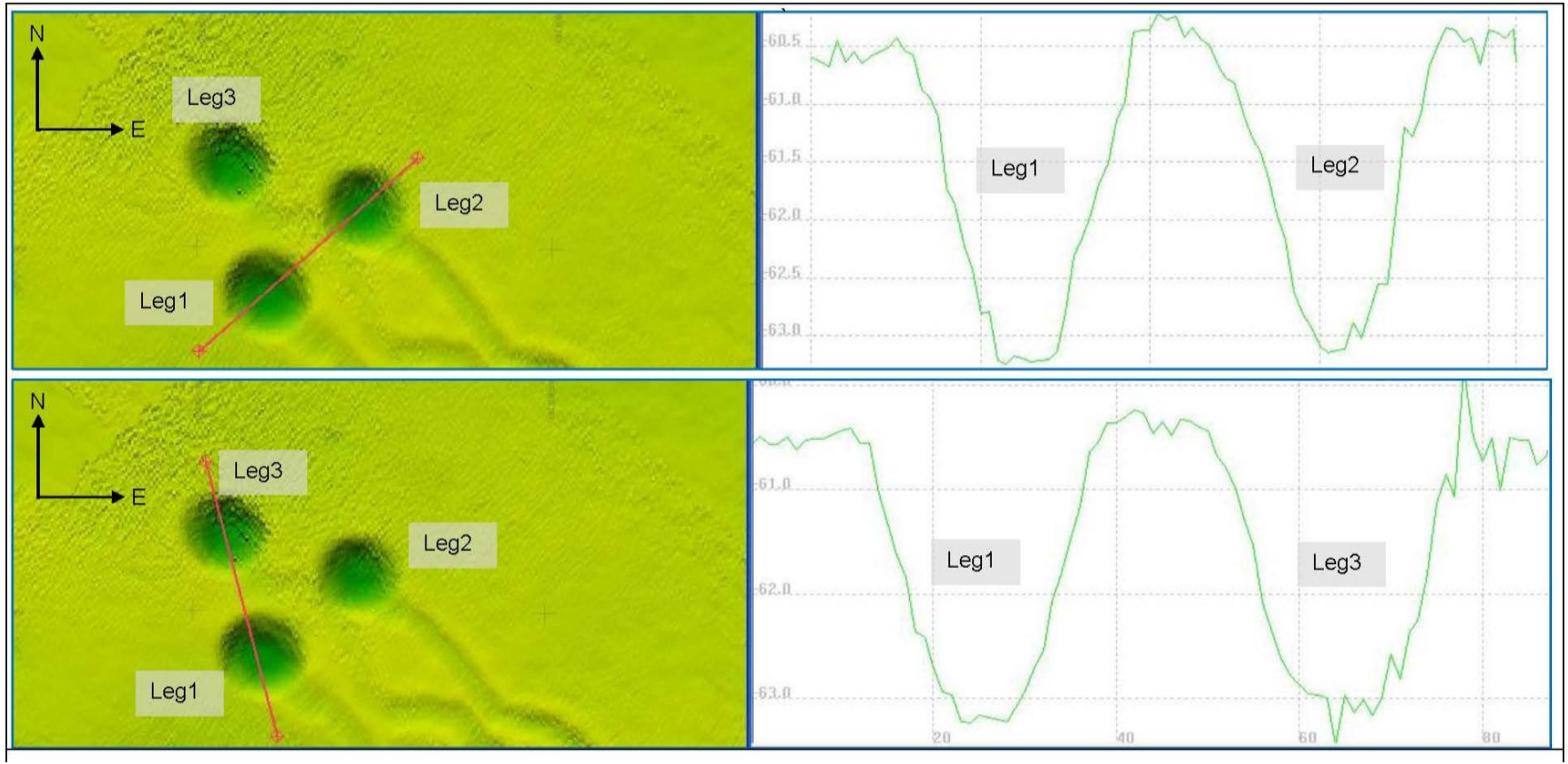

(b)

Figure 1. (a) footprints in the seabed due to deployment of jack-up unit at the site of first case(b) Jack up Footprints cross Profile (unit of axis is meter)

does not apply in the case due to variation in moist content and time effect.

It may be mentioned that the cone factor applied for evaluating the strength ratio is considered to be the same for both conditions of soil.

\subsection{Case 2 (Phase 14-SPD 14A)}

The site for the second case was $62.7 \mathrm{~m}$ below the water surface. The soil had been investigated before deployment of the rig by carrying out CPTU and detailed laboratory tests. In this case the clay was in very soft condition with $20 \mathrm{~m}$ depth. Table 2 shows the soil properties.

Table 2: Soil properties at the site of second case

\begin{tabular}{llllc}
\hline $\begin{array}{l}\text { Depth of } \\
\text { layer below } \\
\text { mud line }(\mathbf{m})\end{array}$ & $\begin{array}{l}\text { Soil } \\
\text { type }\end{array}$ & $\begin{array}{l}\mathbf{S}_{\mathbf{u}} \\
\left(\mathbf{k N} / \mathbf{m}^{2}\right)\end{array}$ & $\begin{array}{l}\boldsymbol{\varphi}^{\prime} \\
(\text { degree })\end{array}$ & $\begin{array}{l}\text { Effective } \\
\text { Unit wt. } \\
\left(\mathbf{k N} / \mathbf{m}^{\mathbf{3}}\right)\end{array}$ \\
\hline $0-20$ & clay & 6 & ---- & 7 \\
\hline
\end{tabular}

Note: $\mathrm{Su}$-Undrained shear strength, $\varphi^{\prime}$-drained angle of internal friction
The actual penetration of spudcans was $20 \mathrm{~m}$. Again the jack-up was a three-legged unit with an equivalent spudcan diameter of $12.1 \mathrm{~m}$. After removal of the jack-up rig, in addition to geotechnical investigation, geophysical investigation was also performed to ensure the safety during installation of a fixed jacket type platform near the footprints. The area mapping result is shown in Figure 2 where the footprints are clearly visible.

CPTU tests along with some index tests like torvane on recovered samples were efficient in determining the condition of the soil in the area.

At the center of the jack-up footprints, the soil was completely remolded and very soft. The ratio of undrained shear strength of original soil to disturbed soil was found to be 10 .

The diameters of the footprints discovered to be in the range of 1.88 to 2.05 times of the spudcan diameter. The depressions in the three footprints were in the range of $1.8 \mathrm{~m}$ to $2.3 \mathrm{~m}$. Most disturbed soil conditions were found at the center of the footprints 


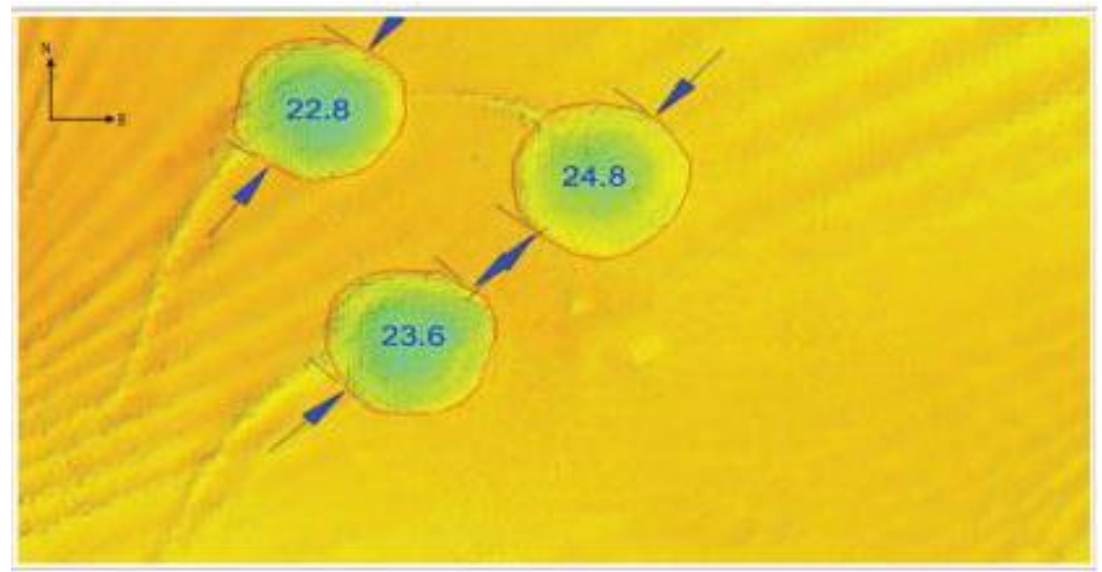

(a)

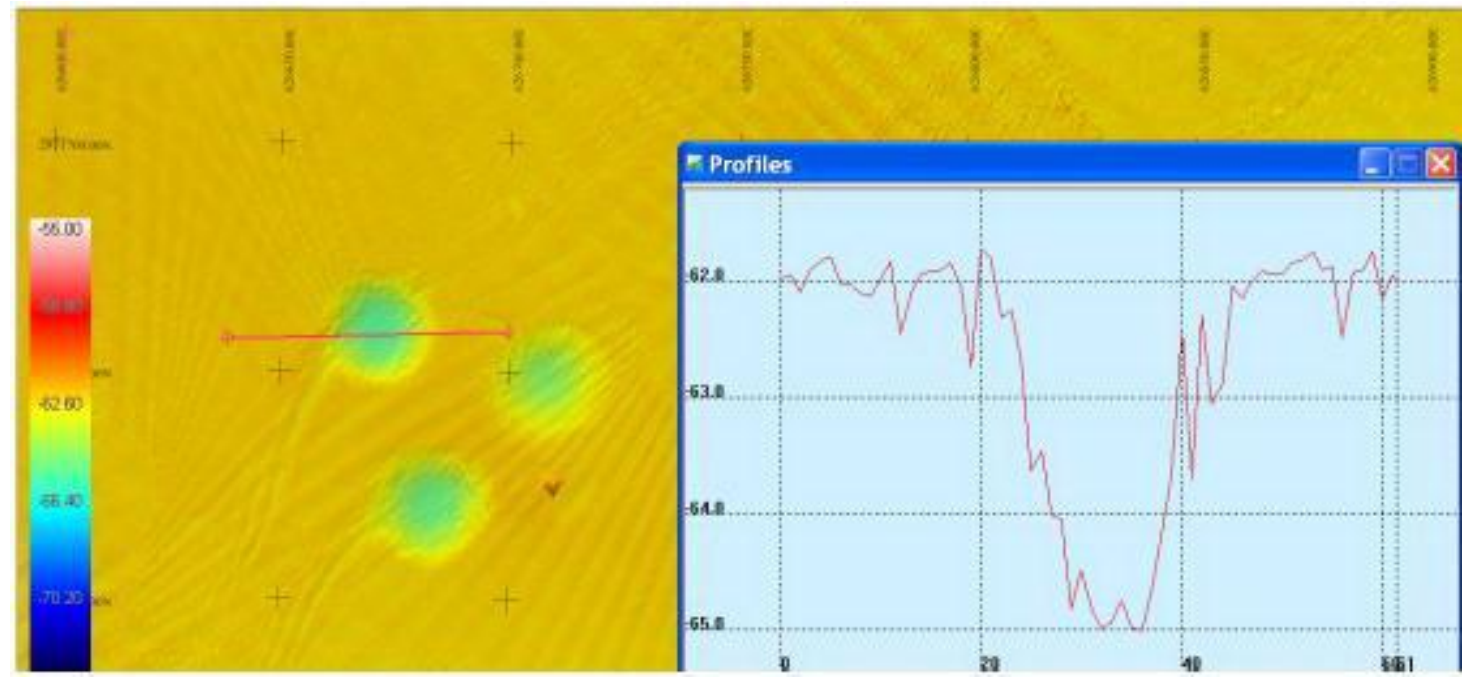

(b)

Figure 2. (a) Footprints in the seabed due to deployment of jack-up unit at the site of second case (b) Cross Profile on Footprint of Jack up Bow Leg for one leg (unit of axis is meter)

(where the spudcan actually penetrated). Disturbance reduced to the distance away from the central of the footprint and it was found to be negligible at the periphery of the footprint. In the intermediate position between two footprints, the soil was disturbed to some extent.

\subsection{Case 3 (Phase 14-SPD 14D)}

In this case the water depth was $74 \mathrm{~m}$. The soil condition is presented in Table 3. These soil parameters were established before the deployment of a rig through detailed investigation by performing CPTU and detailed laboratory tests on recovered soil samples. The soil profile is comprised of clay up to $20 \mathrm{~m}$ depth.

Table 3: Soil properties at site of third case

\begin{tabular}{llllc}
\hline $\begin{array}{l}\text { Depth of } \\
\text { layer below } \\
\text { mud line }(\mathbf{m})\end{array}$ & $\begin{array}{l}\text { Soil } \\
\text { type }\end{array}$ & $\begin{array}{l}\mathbf{S}_{\mathbf{u}} \\
\left(\mathbf{k N} / \mathbf{m}^{2}\right)\end{array}$ & $\begin{array}{l}\boldsymbol{\varphi}^{\prime} \\
(\text { degree })\end{array}$ & $\begin{array}{l}\text { Effective } \\
\text { Unit wt. } \\
\left(\mathbf{k N} / \mathbf{m}^{\mathbf{3}}\right)\end{array}$ \\
\hline $0-20$ & clay & 26 & ---- & 7 \\
\hline
\end{tabular}

Note: $\mathrm{Su}$-Undrained shear strength, $\varphi^{\prime}$-drained angle of internal friction

The rig like other cases was a three-legged unit. The equivalent spudcan diameter was $15 \mathrm{~m}$ and the average penetration of the legs was around $20 \mathrm{~m}$. After the withdrawal of the rig from the site, soil investigation was carried out at the three footprints of spudcans and the diameters of the footprints were seen to be in the range of 1.67 to 1.93 times of the spudcan diameter.

Depressions are in the range of $2.4 \mathrm{~m}$ to $3.1 \mathrm{~m}$ below the general seabed as are shown in Figure 3 (a) \& (b). Reduction of undrained strength was evaluated for the top $20 \mathrm{~m}$ soil. Before and after deployment of rig, cone resistance was considered for evaluation of the undrained shear strength. The average ratio of soil strength reduction was 10 . 


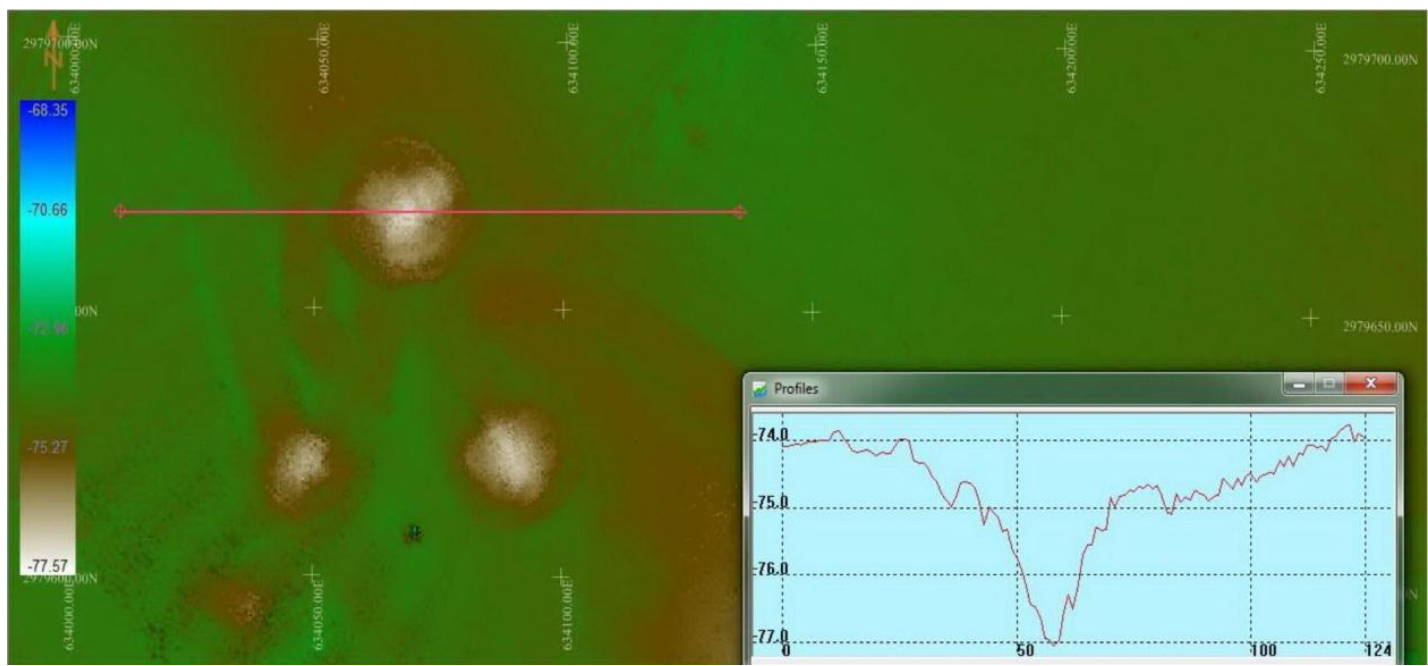

(a)

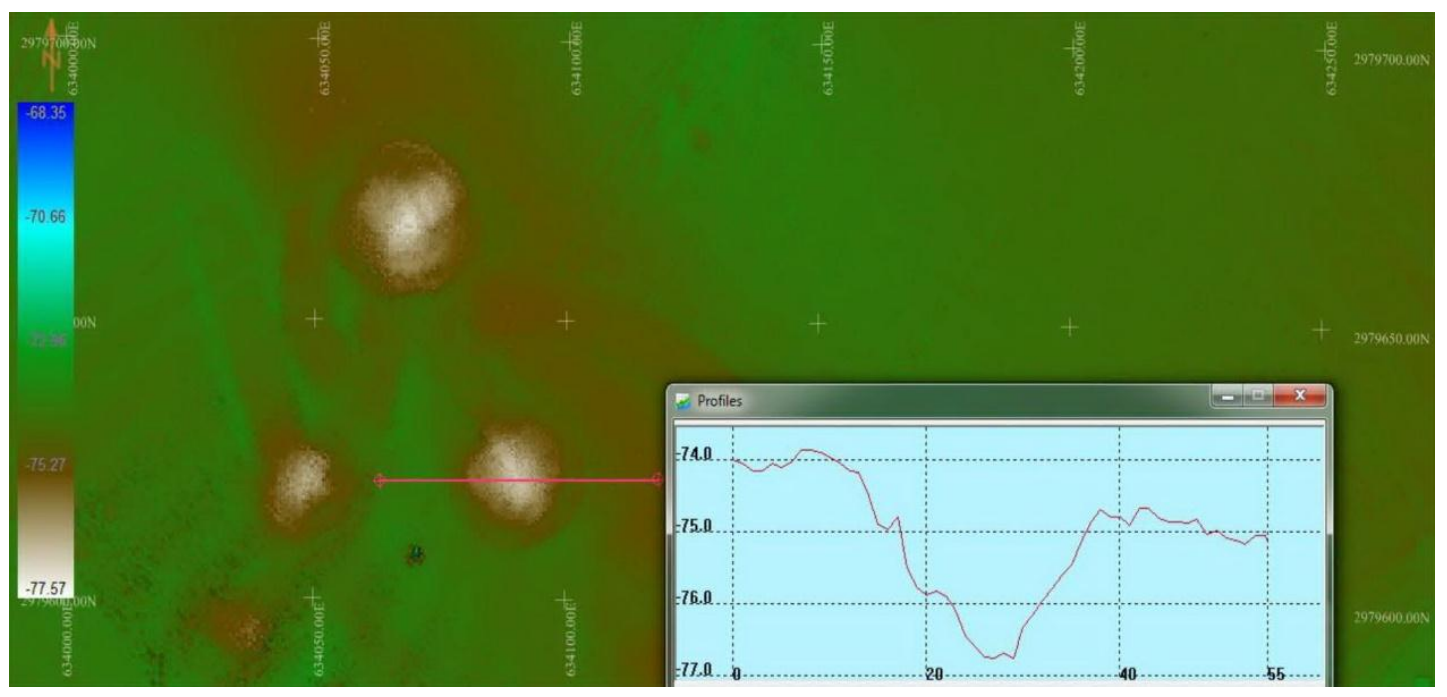

(b)

Figure 3. (a) \& (b) Footprint Cross Profile for one leg at the site of third case (unit of axis is meter)

\subsection{Case 4 (Phase 13-SPD 13C)}

Basically soil has been remolded through the penetration and extraction of $13 \mathrm{~m}$ diameter spudcans. This remolding was caused $26 \mathrm{~m}$ diameter depressions of seabed that they approximately had 3 $\mathrm{m}$ depth. In this phase the jacket platform should be temporarily supported during installation by a 28.688 $\mathrm{m} \times 32.575 \mathrm{~m}$ mudmat area before piles was driven. During installation, the mudmat will be subjected to combined vertical, horizontal and moment (VHM) loading resulting from an eccentric gravity load and environmental actions. Figure 4 shows the position of the footprints.

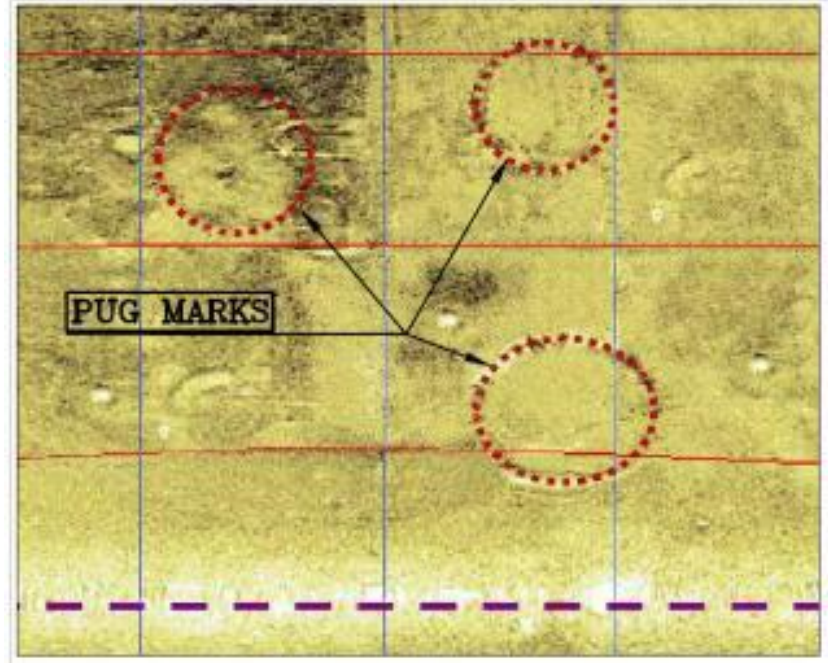

Figure 4. Footprints location at the site of fourth case

The soil conditions at the site consist of layers of clay. The top soil layer contains very soft clay up to a depth of about $20 \mathrm{~m}$. This layer is underlain by a medium stiff clay layer from 20 to $30 \mathrm{~m}$ depth. According to the data from the geotechnical 
investigation, two zones around the footprints were defined: a disturbed zone and an intact zone. Soil characteristics of different layers are presented in Table 4. The layers of depth and seabed depression profile are shown schematically in Figure 5.

Table 4. Characteristics of soil layers

\begin{tabular}{|c|c|c|c|c|c|}
\hline \multirow{2}{*}{ Soil type } & \multicolumn{4}{|c|}{ Intact clay } & \multirow{2}{*}{$\begin{array}{c}\text { Remolded } \\
\text { clay }\end{array}$} \\
\hline & Layer 1 & Layer 2 & Layer 3 & Layer 4 & \\
\hline $\begin{array}{l}\text { Submerged } \\
\text { Unit Weight } \\
\left(\mathrm{kN} / \mathrm{m}^{3}\right)\end{array}$ & 6.9 & 8 & 8.9 & 10.2 & 6.9 \\
\hline $\begin{array}{l}\text { Young } \\
\text { Modulus } \\
\mathrm{E}(\mathrm{kPa})\end{array}$ & 100 & 510 & 1080 & 2215 & 35 \\
\hline $\begin{array}{l}\text { Poisson's } \\
\text { Ratio }(v)\end{array}$ & 0.49 & 0.49 & 0.49 & 0.49 & 0.49 \\
\hline $\begin{array}{l}\text { Undrained } \\
\text { Shear } \\
\text { Strength } \\
\mathrm{S}_{\mathrm{u}}(\mathrm{kPa})\end{array}$ & 18 & 100 & 100 & 300 & 8 \\
\hline
\end{tabular}

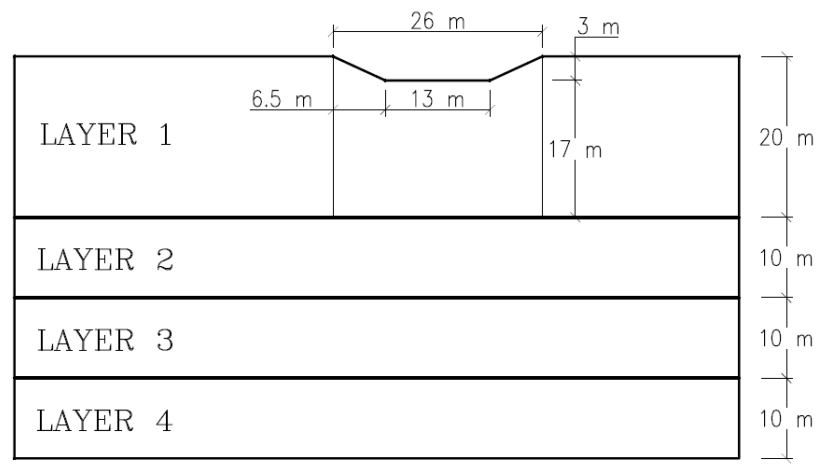

Figure 5. Sketch of Soil layers and soil surface position

\section{Geometry of the Problem}

A 3D finite element model for case phase 13-SPD 13C was undertaken. The lateral dimensions of the model are $90 \times 90 \mathrm{~m}$. The model thickness is $50 \mathrm{~m}$ assuming previously described soil stratigraphy. These dimensions were selected in such a way that the model boundaries have negligible effect on the results. As shown in Figure 5, a cylindrical zone of $26 \mathrm{~m}$ radius in the top clay layer is considered to be fully remolded by the prior penetration of the spudcan at the footprint. In this area, a seabed depression of $3 \mathrm{~m}$ is considered.

The soil layer is divided into two zones: the first zone, the damaged zone, which the spudcan is penetrated into, and the second zone. The first Zone is a cylinder with a radius of $26 \mathrm{~m}$ and the width of other zone is $50 \mathrm{~m}$. These zones are shown in Figure 6. It was shown that the soil layer is affected obviously in the first zone, which is two times the spudcan's diameter $[8,1]$.

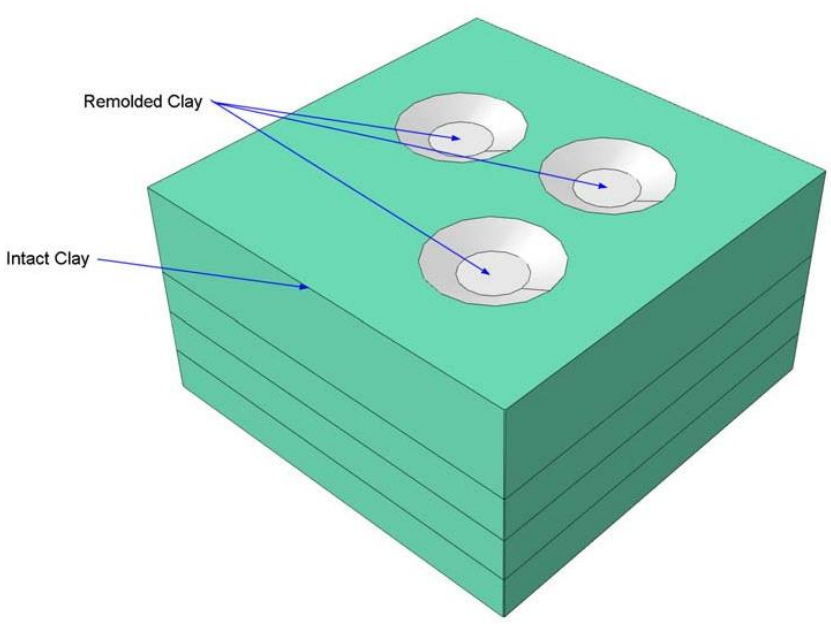

Figure 6. Intact clay and remolded clay

Mesh was produced after the geometry creation of the problem. The mesh comprises a number of 8nodded hexagonal elements with reduced integration. The mesh global coarseness was set to "Medium" and the average element size was about $2 \mathrm{~m}$.

The bottom is fixed, e.g. $U_{X}=0, U_{Y}=0, U_{Z}=0$. The surface is free. The normal fixed conditions are adopted in other boundaries. The initial earth stresses are applied before the penetration of spudcan.

Preliminary analyses were first performed for the base case without a footprint and for which analytical solutions exist. The aim was to check for any effects due to mesh size on the accuracy of the solution. The soil was modeled as an isotropic elastic-perfectly plastic continuum, with failure described by the Mohr-Coulomb yield criterion. The clay layers are assumed to behave "undrained" and are described by a cohesion equal to the undrained shear strength $S_{u}$ with $\mathrm{u}=0$. The elastic behavior was defined by a Poisson's ratio $=0.49$, and Young's modulus (E). The seabed is assumed to be perfectly flat below the mudmat.

Load case where the moment and horizontal loads act along the diagonal of the mudmat in the direction of the footprint were analyzed. The most critical load case was where the moment loading acts in the direction of the footprint.

Piled offshore platforms are fabricated with mat foundations below the jacket frame called mudmats. Mudmat is used for temporarily supporting the jacket structure during installation before the piles are driven to secure the jacket permanently. The size and shape of the mudmat are identified by On-Bottom analysis. On-Bottom Stability before installation of piles is a very important consideration for any piled jacket structure. The critical load case was extracted from On-Bottom Stability analysis of jacket Phase 13-SPD 13C.These loads that were excreted on mudmat are presented in Table 5. 
Table 5. Exerted load case

\begin{tabular}{ccccc}
\hline $\mathbf{F}_{\mathbf{x}}(\mathbf{k N})$ & $\mathbf{F}_{\mathbf{v}}(\mathbf{k N})$ & $\mathbf{F}_{\mathbf{Z}}(\mathbf{k N})$ & $\mathbf{M}_{\mathbf{x}}(\mathbf{k N} . \mathbf{m})$ & $\mathbf{M}_{\mathbf{Y}}(\mathbf{k N} . \mathbf{m})$ \\
\hline 428.289 & 32.292 & 14387.896 & 12187.245 & 40323.938
\end{tabular}

\section{Analyses result}

The purpose of the analysis has two aspects: first to check the stability of mudmat when subjecting between three footprints like the fourth case and the second to assess any tilt during mudmat settlement when it is placed in various distances from footprints. The model of Phase 13-SPD13C was used for verification.

Then the stability of mudmat for case Phase 13SPD13C was checked; while the mudmat was positioned between footprints. This situation causes jacket sliding like Phase13-SPD 13C jacket which slid and sunk into the water practically. The results of the analysis have been presented. Displacement of mudmat, vertical stress in the soil and the tilt of mudmat is presented in Figures 7,8 and 9 respectively.

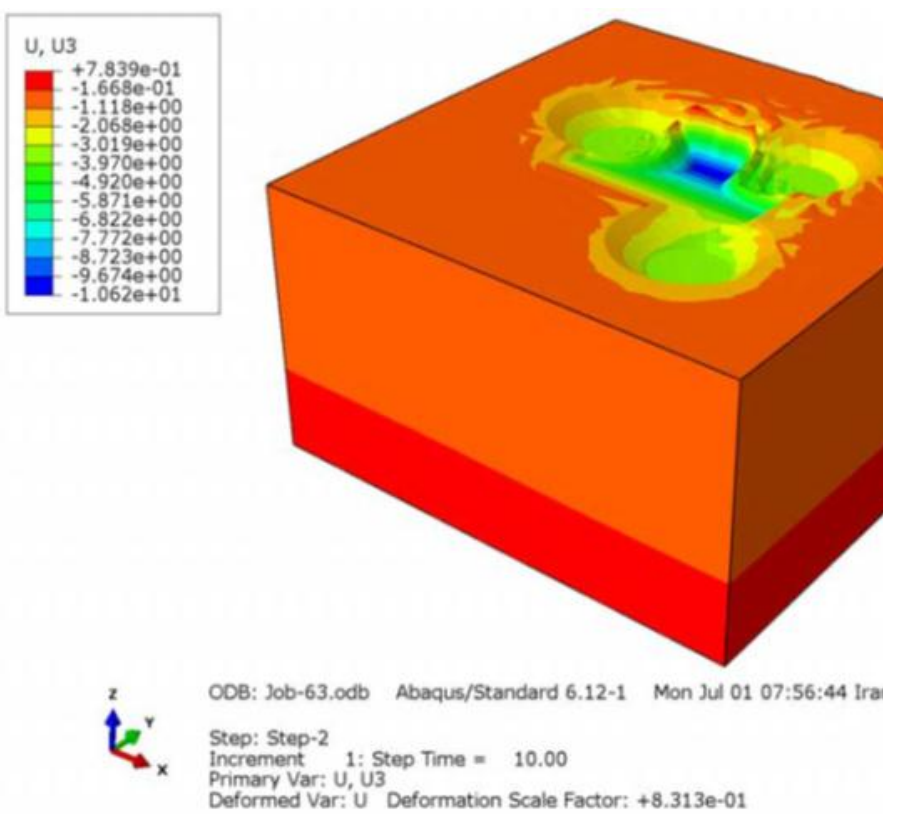

Figure 7. Displacement of mudmat in case Phase 13-SPD 13C

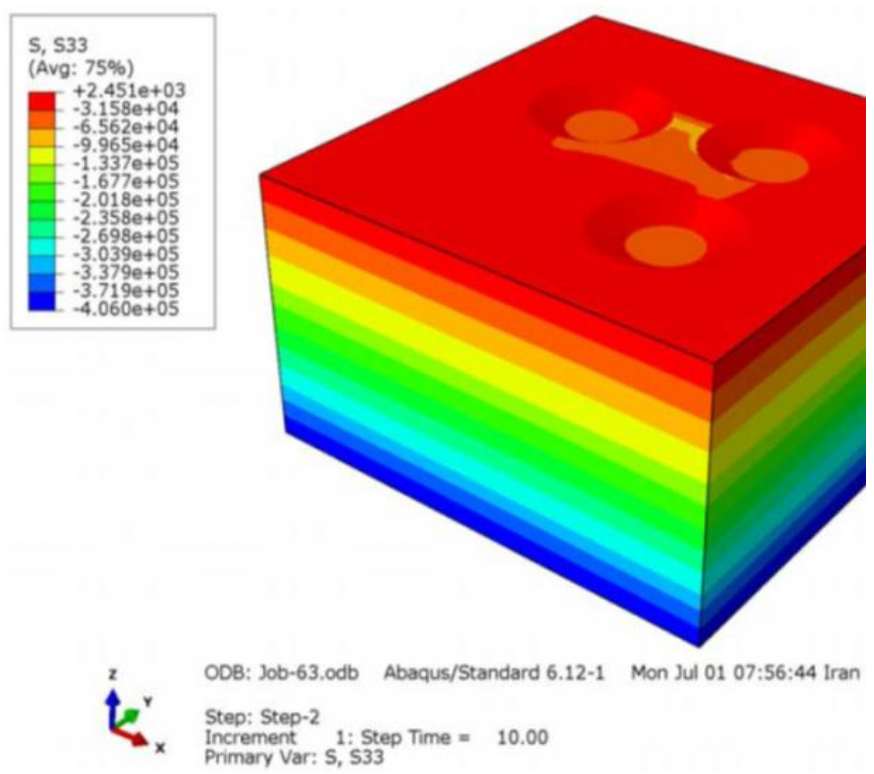

Figure 8. Vertical stress in soil in case Phase 13-SPD 13C

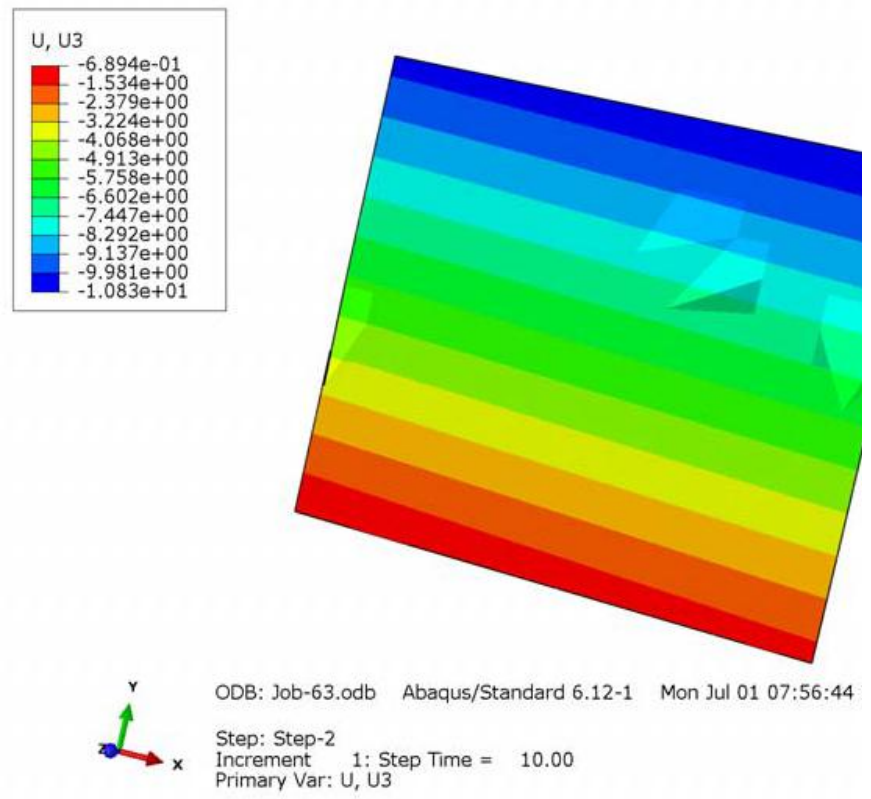

Figure 9. Tilt of mudmat in case Phase 13-SPD 13C

It can be concluded that the soil between three footprints has no strength and mudmat is unstable. As seen in Figure 9 the rotation of mudmat is $5.8 \mathrm{~m}$ and the structure is on unstable position.

This analysis was repeated for different positions of mudmat related to footprints for all cases. The mudmat is placed in different locations from the center of footprints in Figure10 (a) to be far from the footprints like Figure10 (b) until the vertical displacement, horizontal displacement and rocking of mudmat becomes lower than the allowable limit. The main result that comes from the analysis is the examination of safe distance of the mudmat from the edge of the disturbed zones. 


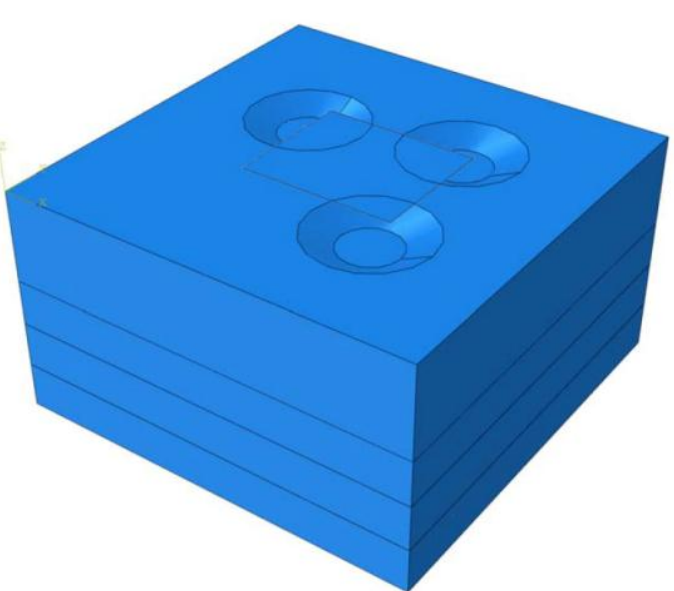

(a)

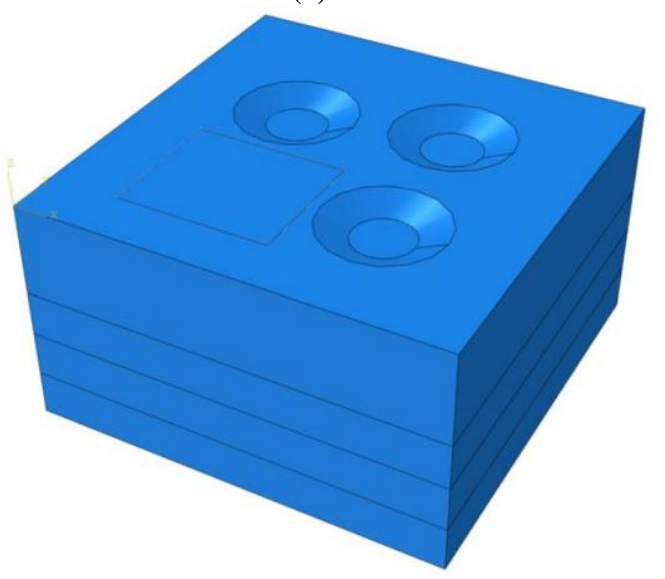

(b)

Figure 10 (a) \& (b). Different positions of mudmat

According to the results, the tilt of the platform is substantial and the platform is unstable near the disturbed zone. Figures 11, 12 and 13 show the sample deformation of soil under the platform, vertical stress distribution and tilt of platform respectively.
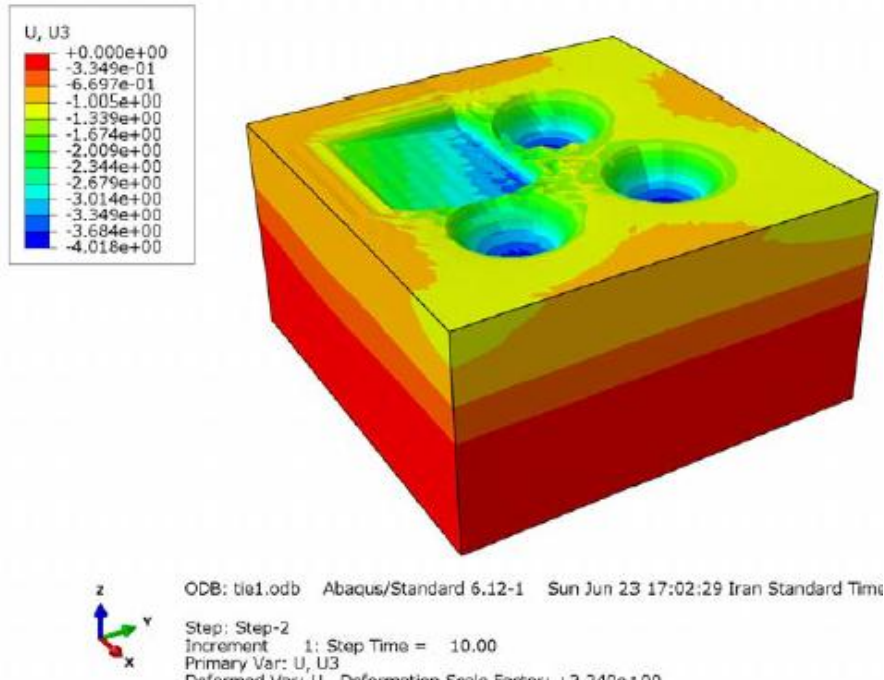

ODB: tie1.odb Abacus/Standard 6.12-1 Sun Jun 23 17:02:29 Iran Standard Tim

Step: Step-2

Increment 1: Step Time $=10.00$

Deformed Var: U D Deformation Scale Factor: $+2.2400+00$

Figure 11: Deformation of soil
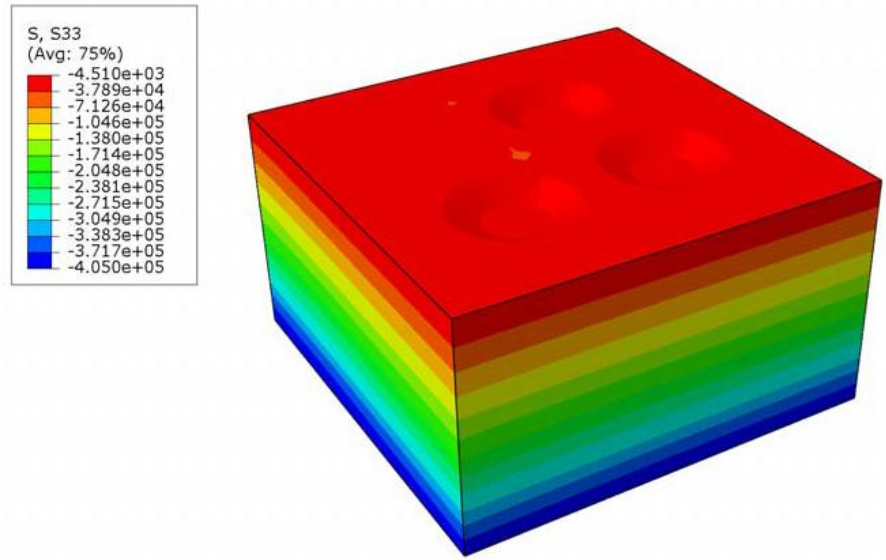

ODB: tie1.odb Abaqus/Standard 6.12-1 Sun Jun 23 17:02:29 Iran Standard Time Step: Step-2

Increment
Primary Var: $S$, S S S3

Figure12. Vertical stress in soil
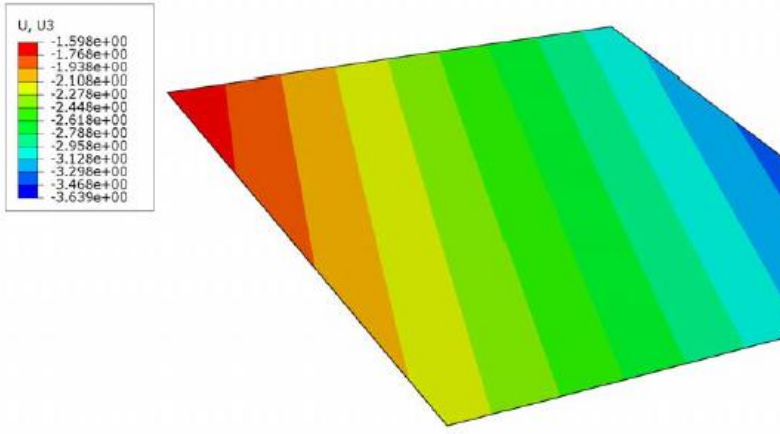

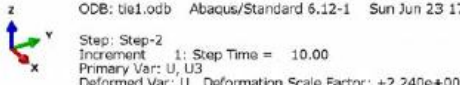

Figure 13: Tilt of platform

When the structure is placed too close to the footprints, the effect of the disturbed zone on the foundation is obvious. The bearing capacity of the foundation will be reduced and the jacket structure is likely to tilt. Safe distance in all analysis for different placement of mudmat was obtained and it is approximately 3-4 meter from the edge of the footprints territory.

\section{Calculation of allowable displacement and rotation of mudmats}

In all cases, deformation of mudmat is calculated according API equations and compared with all results of various models. The maximum of short term deformation for shallow foundation under static or equivalent static loading, affects the structural integrity, serviceability and components of the platform. For foundation materials which assumed to be isotropic and homogeneous and also for the condition where the structure base is circular, rigid and rests on the soil surface, the deformation of the base under various loads is as follows [12]: 
Vertical: $\quad u_{v}=\left(\frac{1-v}{4 G R}\right) Q$

Horizontal: $\quad u_{h}=\left(\frac{7-8 v}{32(1-v) G R}\right) H$

Rocking: $\theta_{r}=\left(\frac{3(1-v)}{8 G R^{3}}\right) M$

$u_{v}, u_{h}$ : vertical and horizontal displacement

$\mathrm{Q}, \mathrm{H}$ : vertical and horizontal loads

$\theta_{r}$ : overturning rotations

M: overturning moments

$\mathrm{G}$ : elastic shear modulus of the soil

$v$ : Poison's ratio of the soil

$\mathrm{R}$ : radius of the base

These solutions can be used for estimate the response of a square base with equal area.

\section{Discussion and Conclusion}

In order to control and reduce the sliding risk for a jacket platform installation close to an exist footprint, a finite element model was built and its reliability has been verified by a real problem that was happened for a jacket platform in Persian Gulf.

The analyzed cases where providing insights to events at the time when a large footing is penetrated into the seabed. Our measurements and analysis results show the following points:

1. For new foundations the disturbance of the original soil in the footprints may affect in different ways:

a. Spudcan-footprint interaction and uncontrolled movement that cause possible damage to jack-up and adjoining structure while deploying the rigs.

b. Tendency of instability/tilting of structures like fixed jacket platform while supported on mudmats during installation.

2. Main result that was achieved in all analyses is the finding of secure space between the mudmat and the side of disturbed zone. This is a critical assessment for offshore installation. A safe distance of the mudmat from jack up footprints territory is approximately 3-4 meters in clayey soils.

3. Maximum remolding / remixing of soil occurred at the center of the footprints. The remolding reduces towards the periphery of the disturbed zone. The diameter of footprints was in the range of 1.5 to 2 times of spudcan diameter in soft to firm clays.

4. Maximum depression in the seabed that remained after the withdrawal of the jack up rig was in the range of 2 to $3 \mathrm{~m}$ in the center of footprints. It is in very soft and soft clays near the seabed. Depth of depression calculated in the range of $15-22 \%$ of the spudcan diameter.

5. The undrained shear ratio of original to disturbed clayey soil was 10 . This Value is close to the sensitivity of clays in the areas.

There is a lot of scope for further research on all these aspects through field measurements, laboratory testing, and model testing and analytical techniques. Taken together consider the cost and safety of offshore structures; it is logical to be conservative while taking into account risky effects on design and installation of foundations at or near such the disturbed soil zones.

\section{Acknowledgment}

We would like to thank Iran Marine Industrial Company for their support on data collection.

\section{References}

1- Mahanta, R., Sharma, S.C., Ajit, A. and Ghanekar, R.K., (2012), The Effect of Deployment of Jack-up Drilling Units on Clayey Soils at Offshore LocationsCase Studies, Proceeding of Indian Geotechnical Conference, pp.B238.

2- Dongfeng, M., Minghui, Z., Laibin, Z., Menglan, D. and Linsong, S.,(2015), Sliding risk of jack-up platform re-installation close to existing footprint and its countermeasure, Petroleum Exploration and Development, Vol.42.

3- Tan, X.M., Guo, J.Y. and Lu, C.,(2006), Effect of spudcan penetration on neighboring existing pile, International Society of Offshore and Polar Engineers, pp.516-523.

4- Boulon, M., (1989), Basic features of soil structure interface behavior, Computers and Geotechnics, Vol.7, pp.115-131.

5- Mostafa, Y.E. and Naggar, M.H.E., (2004), Response of fixed offshore platforms to wave and current loading including soil-structure interaction, Soil Dynamics and Earthquake Engineering, Vol.24, pp.357-368.

6- Ding, H. Y., Liu, J. H. and Zhang, C., (2004), Analysis of effects of the drawing of spudcan on the cylinder foundation by FEM, China Offshore Oil and Gas, Vol.16, pp.353-356.

7- Xie, Y., Leung, C. F. and Chow, Y. K., (2006) Effects of spudcan penetration on adjacent pile, International Conference on Physical Modeling in Geotechnics, Hong Kong, Vol.1, pp.701-706.

8- Yongren, R. W., Xiaobing, L. and Xuhui, Z., (2010), Effects of the Spudcan Penetration on the Adjacent Foundations, the Open Ocean Engineering Journal, Vol.3, pp.38-44.

9- The Society of Naval Architects and Marine Engineers, Guidelines for Site Specific Assessment of Mobile Jack-Up Units, Technical \& Research Bulletin 5-5A, (2002).

10. Pierre, L. T. and Christian, P., (1997), Stability and operation of jack-up s, Editions Technip, Paris. 11- Lunne, T., Robertson, P.K. and Powell, J. J. M., (1997), Cone Penetration Testing in Geotechnical Practice, Blackie Academic and Professional, An imprint of Chapman \& Hall, U.K.

12- API (Recommended practice for planning, designing and constructing fixed offshore platforms- 
Zahra Omrani, Rouhollah Amirabadi / Effect of the Spudcan's Footprints on Adjacent Jacket's MUDMAT in Clayey Soil-Case Study

working stress design), American Petroleum Institute, (2014). 